\title{
The Democratisation Myth: Open Access and the Solidification of Epistemic Injustices
}

\author{
Marcel Knöchelmann \\ University College London, United Kingdom; Yale University, USA/ marcel.knochelmann.15@ucl.ac.uk
}

\begin{abstract}
Open access (OA) in the Global North is considered to solve an accessibility problem in scholarly communication. But this accessibility is restricted to the consumption of knowledge. Epistemic injustices inhering in the scholarly communication of a global production of knowledge remain unchanged. This underscores that the commercial or big deal OA dominating Europe and North America have little revolutionary potential to democratise knowledge. Academia in the Global North, driven by politics of progressive neoliberalism, can even reinforce its hegemonic power by solidifying and legitimating contemporary hierarchies of scholarly communication through OA. In a critique of the notion of a democratisation of knowledge, I showcase manifestations of OA as either allowing consumption of existing discourse or as active participation of discourse in the making. The latter comes closer to being the basis for a democratisation of knowledge. I discuss this as I issue a threefold conceptualisation of epistemic injustices comprising of testimonial injustice, hermeneutical injustice, and epistemic objectification. As these injustices prevail, the notion of a democratisation of knowledge through $O A$ is but another form of technological determinism that neglects the intricacies of culture and hegemony.
\end{abstract}

Keywords: Epistemic Injustice, Democratisation of Knowledge, Scholarly Communication, Open Access, Recognition, Social Epistemology

\section{Introduction}

\section{Openness, democratisation, and prevailing imperialism}

Discourses and practices around open access to scholarly publications (OA) in academia in the Global North often treat a narrow notion of accessibility as a pressing problem and, in return, offer wider readership access as a solution. More radical or bottom-up approaches conceptualise accessibility more widely with the result that it is not readership but active, participatory access to discourse that is to be problematised. While there are bottom-up initiatives in all parts of the world, large-scale initiatives within the Global North still

receive the majority of investments and retain the hegemonic order. This tends to blind for wider notions of accessibility: that is, who is allowed to publish where, for what reasons, and what are the non-materialist, cultural premises. It can be argued: wider accessibility is primarily a matter of recognition, while narrow accessibility is one of redistribution only.

$I$ argue that $\mathrm{OA}$, and the narrow accessibility problem it is said to solve, are ill-equipped: they do not lead to positive social change or a democ- 
ratisation of knowledge but reinforce a Global Northern knowledge hegemony. Indeed, the implementation of $\mathrm{OA}$ in academia in the Global North demonstrates how it solidifies inequities in scholarly communication: it largely manifests the proprietary communication structures of established publishers and shows no change regarding epistemic injustices. Moreover, that $\mathrm{OA}$ is signified as a normative good disguises that it, in fact, solidifies these inequities. There is growing evidence that, by building on the narrow accessibility problem, subjects pushing for large-scale $O A$ initiatives in academia in the Global North such as national OA deals, or for more OA even in commercialised form (exemplified in the UK: Finch, 2012; or Germany: Projekt DEAL, 2019), are not interested in democratising knowledge but seek to retain owning and governing the means of communication. These modes of ownership and governance are fundamental constraints on a democratisation of knowledge in a global perspective. This globalisation is, thus, but an expansion of ideals of the Global North instead of an inclusive engagement of local particularities in a global context, driven by the imperatives of rankings and the rhetoric of a Global Northern notion of quality and reputation.

The concept of epistemic injustice is crucial for understanding the shortcoming of $\mathrm{OA}$ in the light of a democratisation of knowledge. It provides theoretical grounds for forms of injustice that a minority social group faces because either their testimony is doubted, or their experiences do not find corresponding representation in the hermeneutical resources of the majority. Epistemic injustices are a central problem in scholarly communication and the illusion of a real openness of OA disguises that its current large-scale modes of implementation reinforce these injustices.

\section{State of discourses}

Conceptions of these issues are available, yet underdeveloped in their connection of theory and manifestation, or of $\mathrm{OA}$ and injustice more generally. There are mostly unconnected contributions and discourses about $\mathrm{OA}$, its unachieved potential for a democratisation, or epistemic injustices in the context of academic imperialism.
Implied is the notion of democratisation through mutual sharing of knowledge in one of the founding documents of OA which states that this publishing mode is supposed to "share the learning of the rich with the poor and the poor with the rich" (Budapest, 2002; you may find similar terms in: Berlin, 2003; Bethesda, 2003). Like crossing the Rubicon, this statement leads the way to holding $O A$ accountable to its implicit ideals. One of the earliest to discuss a democratisation of knowledge through $\mathrm{OA}$ and, thus, making this ideal explicit, has been Willinsky (for instance: 2006). As an early strong OA advocate, he introduces aspects of the social epistemology of scholarship, engaging with the work of Longino (2002; see also: Willinsky, 2006, chapter 2) as well as with Sen (1999) and Canagarajah (2002). Within his consideration of the need of a democratisation of knowledge and the ways OA might help achieve this (Willinsky, 2006, chapter 7), Willinsky looks at structural improvement and warns about the extension of a Western colonisation of knowledge, instead of local empowerments, early on. What he did not foresee is how forms of large-scale implementation of OA in academia in the Global North achieve to extend their hegemonic colonisation. Nevertheless, the founding of the Public Knowledge Project and the provision of technological means such as infrastructure, especially the Open Journal System, have been vital steps towards a substitution of established infrastructures. The development of OA is itself closely connected to the development of open source and software (Tennant et al., 2020). See in this respect also the interconnectedness of socio-cultural practices and technology, driving potential for change in circular reinforcement (Okune, 2020). The importance of such technological means cannot be stressed enough. Still, though, the recent work on continuing injustices proves that technology alone is not enough.

Quite the contrary, technology can likewise provide the means for a continuation of dominant politics and ideals. Recent developments revived the discourse on the democratisation of knowledge. Both Holbrook (2019) and Inefuku (2017) are wary of the trajectory of OA regarding achieving its ideal. Though they emphasise positive aspects of some OA developments, their 
strong criticism dominates: Holbrook is highly critical of the unlikely democratising and equalising impact recent large-scale implementations of OA may have, while Inefuku remains critical of its cultural impact and implicitly signals a sort of technological determinism. Sengupta (2021) goes further and explicates the academic colonialism that OA pursues. Chan and Gray (2020) further argue that OA can help achieving to break a hegemonic order, but it remains to be outlined and maintained globally how new principles may look like.

In close relation to the democratisation of knowledge, but distinct in its discursive formation, there is a broad range of work on cognitive, intellectual, or knowledge imperialism. Bhargava (2013: 415) articulates "a loss of epistemic autonomy" where a colonising society shapes the culture principles, identity frameworks, or heritages of a minority. Alatas (2000) is similarly vocal about this issue and illustrates both the political and historical foundations of intellectual imperialism as well as contemporary manifestations. Among others, he accounts for publishing practices that result in a disregard of local discourse such that

there is more scholarship on our region [Singapore] done abroad, reviewed abroad, assessed abroad and consumed here. Therefore, there is less scholarly debate locally (Alatas, 2000: 30).

Important in this respect is also the discussion of centre/periphery (or periphery/semi-periphery), articulating the appropriation of practices of knowing and understanding by foreign discourse (see, for instance: Lander, 2000; Luczaj, 2020; Monteiro and Hirano, 2020; Rodriguez Medina, 2015; de Sousa Santos, 2016). Marginality or periphery can take on various forms here, such as building on rendering notions of geography, history, minority, or, more elusively but pertinent for my argument: the epistemic other. This often, but not necessarily, reflects political-historical dimensions of colonisation just as the notions of Western or Global South/North do (see below for a terminological differentiation for this article).

Further in this line of critique is the matter of academic dependency, as outlined by Alatas (2003) or Andrews and Okpanachi (2012). Alatas discusses the implicated academic imperialism beginning with "the setting up and direct control of schools, universities and publishing houses by the colonial powers" (Alatas, 2003: 601; emphasis added) which directly connects to my argument. By making the means of digital access to established discourse available, publishing houses of the Global North extend their epistemic reach on a worldwide scale so that academic dependency prevails. Thus, mere access to past discourse is not as such a democratisation of knowledge but, first of all, the potential for academic dependency. Alatas defines various such dependencies, some of which relate to cognitive modes. Precisely those modes are the issues that I aim to define in more detail by discussing epistemic injustices. Vital in this regard is also the work of Ogone (2017: 33) who outlines different epistemic injustices and concludes that "only by means of a vibrant tradition of scholarship that African thinkers can succeed in deconstructing the prevailing knowledge hegemony in pursuit of epistemic justice".

Does the openness - and the notion of democratisation said to underpin this openness-in OA allow for more of such vibrant tradition, or to overcome epistemic injustices? This is to be regarded quite nuancedly, of course. On the one hand, there is a broad discourse on the technicalities of implementing OA (see, for instance: Björk, 2012; Bosman and Kramer, 2018; Brehm and Neumann, 2018; Eve et al., 2017; Eysenbach, 2006; Martín-Martín et al., 2018; Tanner, 2017). Discussions in favour of OA can be encountered in politically more radical versions (Swartz, 2008; Swartz and Lessig, 2016) as well as conservative or neoliberal ones (Crossick, 2016; Finch, 2012). Moreover, ideological centring of $\mathrm{OA}$ often inheres - though mostly only implicitly-in notions of knowledge as a public good (Hess, 2012; Hess and Ostrom, 2011; Moore, 2019; Suber, 2009) or universal access to knowledge (Bowman and Keene, 2018; Tennant et al., 2020). More fundamental theoretical discussions on moral implications such as the contribution by Bacevic and Muellerleile (2017) are rather rare.

On the other hand, there is a diversity of radical approaches towards OA. There are, for instance, South or Latin American approaches which are 
prominently represented by AmeliCA or Redalyc. These approaches aim to foster a democratisation in that they build on regional and scholar-driven infrastructures (Aguado-López and BecerrilGarcia, 2019; Becerril-García, 2019). Such scholardrivenness, or being scholar-led, can in newer initiatives also be found in the Global North, for instance in the Radical Open Access Collective or ScholarLed. Of particular importance here is that small-scaling OA publishers are set-up to replace or provide alternatives to existing, established publishers (Barnes, 2018). The notions of smallscaling and scholar-led indicate the desired diversity and closeness to scholarly endeavours, thus, being a service within the scholarly community and its epistemic diversity (Adema and Moore, 2018; Barnes and Gatti, 2019). I further discuss such initiatives below.

What these discourses demonstrate is that a democratisation of knowledge is thematic for $\mathrm{OA}$ in the sense of epistemic freedom. But the two examples for radical $O A$ are small in comparison to, for instance, Projekt DEAL or PLANS (the former is the German coalition for reaching transformative $O A$ agreements with corporate publishers; the latter is a coalition of research funders aiming to advance $O A$ as a transnational agenda; I discuss both in more detail in the section: Narrow Accessibility: Allowing Consumption). These disparate modes of manifestation and their implicated meanings make a comprehensive assessment of the potential of a democratisation of knowledge a pressing topic. Moreover, the discourses on epistemic injustices/academic imperialism and OA seem disunited, so that a unified contribution may help identify pertinent issues: connections between manifestations of $\mathrm{OA}$ and consequential, deeper theoretic conceptions of social epistemology are often missing. Existing contributions in this respect are the collected works of, for instance, Smith and Seward (2020), or Eve and Gray (2020). Particularly the work of Mboa Nkoudou (2020) about redressing OA as a means for epistemic justice as well as Posada and Chen's (2018) about injustices resulting from ownership of publishing infrastructures are vital in this respect. I build on these recent contributions and aim to provide a more thorough conception of social epistemological injustices in the context of scholarly communication and OA. I argue thatfor accessibility to apply in the general sense of a democratisation of knowledge-these injustices need to be overcome.

\section{Structure and terminology of this article}

I proceed in this article by highlighting cases of manifestations of OA that evidence the shallowness of a narrow accessibility problem (section: Narrow Accessibility: Allowing Consumption). These cases underscore the agenda of progressive neoliberalism (Fraser, 2019), that infiltrates academia and is taking advantage of OA in unprecedented ways. Most of all, the cases illustrate that $\mathrm{OA}$ is not driven by the objective to democratise knowledge. I go on to discuss the connection between general accessibility and the democratisation of knowledge (section: General Accessibility: The Democratisation of Knowledge and Epistemic Injustices). I propose three forms of injustices here. This is followed by a discussion where I connect and critically engage the discursive threads of my argument.

A note on terminology: I acknowledge that there is a diversity of approaches to OA within the Global North as well as the term Global North itself having its ideological problems. Regarding the former: there are bottom-up approaches across the globe, as mentioned already. The cases discussed below only illustrate a particular mode of OA that is ill-equipped for matters of democratisation and, nonetheless, receives major financial means in praxis. Regarding the latter: China, a country that is included in the realm of the Global North, shows clear tendencies to gear their practices towards North American/European notions of knowledge. The use of the term Global North, therefore, seems imprecise here. Still, a discursive referent is required.

The use of a Global South/North divide cannot be explained by geographical reference alone, since countries such as Australia and New Zealand are sorted into the Northern cluster. The separation bears connection to the term Third World, which was to "distinguish the formerly colonized or neocolonized world from the modernizing worlds of capitalism and socialism" (Dirlik, 2007: 13). As such, referring to the development stages of Global Southern countries built on the notion 
of a development towards Global Northern ones. Eve and Gray (2020: 11) use these terms in this sense to "refer to a worldwide division in equity of wealth as a result of colonial legacies and ongoing prestige practices". Others deploy Western to refer to what is similarly seen as the Global North, such as Willinsky (2006), Paasi (2015), or Ogone (2017). Again others such as Pitts (2017: 150) synonymise "Western/Global Northern knowledge", or use both terminologies of North/South and Western (e.g.: Smith and Reilly, 2014). The use of such terms can be critiqued for solidifying assumptions or ideologies that are indeed matters of the object to be critiqued themselves. Moreover, more focussed differentiations can also be made where, for instance, a distinction is possible based on publication patters in West European/Nordic and Central/Eastern European countries (Kulczycki et al., 2018). All of this shows that the terminology needs to be handled with caution; nevertheless, Global North is a helpful term to refer to particularly capitalist societies or countries that, as I show in the ensuing analysis below, are responsible for developments influencing countries beyond themselves, both materially and ideologically. It is in this sense that I use the term which means that it refers to dominant practices and ideology without disregarding of the fact that there are many other practices and culture principles at work within the Global North as well. Furthermore, I retain the ambiguity of the terms where, for instance by discussing Paasi or Willinsky, the terminology of Western slips in.

Some notes on methodology: though I do not employ a Marxist critique, as a cultural sociological work, this article stands in close relation to, and draws on, Gramsci and his conception of hegemony. First of all, the ontological perspective needs to be clarified. I follow the cultural sociological paradigm that stresses the relative independency of culture vis-à-vis materiality; that is: the material is mediated by culture instead of vice versa (see for more on this: Alexander, 2005; Alexander and Smith, 2001; Emirbayer, 2004). This is a vital break from conflict theorists whose analytic predominance is the material over culture (for an illustration of the difference, see the contribution of: Gartman, 2007). This by no means determines irrelevancy of conflict or Marxist theory.
Quite the contrary, I draw heavily on it. This only issues a perspectival focus which means in the context of practices concerned with opennessOA, open science, open humanities-that subjects approach the materiality of discourseits artefacts: publications-through the lens of specific culture principles (such as of competition, reputation, or openness eo ipso). The purpose and existence of a publication is mediated by such principles so that different communities perceive publications with different dominant principles. To give an example, where scholar-led approaches consider a publication as a means for the communication of scholarship, large-scale OA initiatives such as those behind Projekt DEAL may tend to consider a publication to also be a means of hierarchical reputation (I illustrate this further in the following chapter). Likewise, disciplinary cultures may pose difficulties for adopting principles of openness in a transdisciplinary manner as the meaning of artefacts and discourse is dissimilar (Knöchelmann, 2019a). Thus, corresponding subjects mediate the artefact through culture which shapes their understanding of it. This brings me to, secondly, the matter of hegemony.

Hegemony in the Gramscian sense is the dominance of particular culture principles which allow for capitalist institutions to persist. In other words, a capitalist worldview, its values and explanations, is diffused throughout society, across classes or societal sub-systems, such that all correspond to this particular worldview. This is the short version of the diversity of concepts referred to as hegemony in Gramsci's Prison Notebooks $(1992,1996)$. That is, within Gramsci's texts themselves, the term is not used unambiguously, connoting quite distinct concepts which, most basically, refer to "mechanisms of bourgeois rule over the working class in a stabilized capitalist society" (Anderson, 1976: 20). Applications of discourse or power analysis by means of hegemonic culture principles is likewise diverse. Pertinently for my argument, Moore works with the concept of hegemony and issues that "[s]ubscription publishing is the current common sense of humanities publishing [...] and certain articulations of OA pose a counter-hegemonic threat" (Moore, 2019: 27). In a similar methodological approach, Knoche discusses OA and the 
hegemony of profit-oriented publishing and reputation (Knoche, 2019: 143; further in regards to critical communication studies, see the discussion of ideology critique in: Fuchs, 2020: 228-232). It is in this sense that I deploy the term, though within a cultural sociological fundament.

That this is a cultural issue is vital for understanding my argument, and important for the Science and Technology Studies (STS) discourse more generally. The issue of different modes of accessibility can be seen in the light of a debate over redistribution or recognition in the sense of Fraser and Honneth (2003). Nevertheless, I argue that cultural issues (and, thus, potentially recognition) precede redistribution or technological equality (see also for a discussion of hegemony and ideological struggle in the light of culture analysis: Hall, 1986). STS discourse builds upon the understanding of the intricate interconnectedness of culture and materiality, rejecting notions of disunified ontologies (Latour, 1993). An analysis of material and epistemic means of accessibility and their interconnectedness, therefore, may find a valuable place for dispute within STS.

Further in relation to a critique of hegemony, the matter of belief in principles, practices, and their righteousness stands the Bourdieuian illusio (Bourdieu, 1998: 76). The importance of this category is that individuals actualising practices do so without questioning, or even without intelligibility of, the culture principles and institutionalisations involved. They are, so to say, unintelligible or blind towards the rules of the social game being played (which may not imply they are cultural dopes). Observe as a Bourdieuian illusio, for instance, the systemic unawareness of matters of social closure in respect to the distribution of research funds in Germany (Münch, 2011:276-287; further in a similar methodology, Münch's critique of academic capitalism in Germany: 2007). Matters of recognition, venue publishing, or the individual publication under the guise of journal reputation are particularly pertinent to $O A$ and can be seen as further exemplifications of illusios, since the majority of scholars actualise practices that bear culture principles which they are unaware of. By so doing, they support a hegemonic order: most crudely exemplified by the working of the journal impact factor (Brembs et al., 2013; Brembs, 2018;
Lariviere and Sugimoto, 2018; McKiernan et al., 2019; Vanclay, 2012). The connection becomes more apparent below.

\section{Narrow accessibility: allowing consumption}

There are, in essence, two ways accessibility problems can arise in scholarly communication: by way of accessing the results of past discourses or by way of accessing ongoing and future discourses in their making. The former is the premise upon which large-scale manifestations of OA in academia in the Global North are built: accessible means affordable consumption. This premise exposes a political trajectory: retaining the established order of a Global North hegemony by reducing structural change to affordable consumption. This conception of an accessibility problem resonates the lofty ideal of increasing equity through a one-sided distribution of knowledge. Accessibility, here, is a matter of redistribution only.

\section{Problematising narrow accessibility}

Illuminating for how the fallacy of narrow accessibility slips into even radical OA advocacy is the following example. Tennant et al. (2016) engage an anecdote to support their argument of the democratic impact of allowing more widespread access to knowledge from the Global North. The authors point to a paper (Knobloch et al., 1982) that provides evidence for why Liberia should be within the Ebola endemic zone. Up to and during the 2014 outbreak of Ebola, this paper is supposed to have been unknown to Liberian officials for it was published behind a paywall, the authors argue. OA would have changed this which implies that solving narrow accessibility would have been a solution. But can this argument justifiably be made? I suggest it cannot, for simply tearing down paywalls does not resolve the issue that Knobloch et al. (1982) published their research in a French journal (the Annales de l'Institut Pasteur in France), thus, gaining authorship recognition for a Global North sense of reputation. Tennant et al. (2016) insist that "OA provides a mechanism to level the playing field between developed and developing countries" but they do not work out what this 
mechanism might be. It is implied that allowing others to access knowledge for free constitutes this mechanism. And yet, the anecdote shows that when this mechanism is explicated-that Liberian officials would have incorporated knowledge provided in this article if a paywall would not have been in place-it seems unjustified. Consider the question of why Knobloch et al. (1982) have not published their research in a Liberian or African journal in the first place. It was not a paywall preventing them from so doing.

By focussing on narrow accessibility as a problem in academia, discourses miss to connect the dots between the co-optation of OA by politics of progressive neoliberalism and the failed revolution of a democratisation of knowledge. This politics enabled neoliberal economic principles to become legitimated because of a coating of meritocratic diversity. The appearance of equality allows for hierarchies to continue to exist. In the context of academia in the Global North, solving a narrow accessibility problem provided the established order with a "patina of legitimacy", to utilise the language of Fraser (2019: 15). Those subjects of established scholarly communication that have been strong in the past-corporate publishing, financially well-equipped academic institutions, and research management staff in countries from the Global North-found a way of manifesting their position: they repurposed accessibility as a form of affordability and merely shifted this affordability from the reader to the author (or their institutions).

This co-optation can be shown with a range of cases. And yet, my critique shall not be one of capitalist profit-making as such. Also, I do not intend to represent a diversity of OA approaches divided along the dualisms of corporate/small-scale, established/radical, or capitalist/collaborative. Much rather, with the range of cases discussed in the following, I aim to illustrate the large-scale manifestations in the Global North that receive heavy investment, public attention, and, thus, are firm in their dominant position. As in the tradition of case studies (Flyvbjerg, 2006), these cases are articulating the particularities of a paradigm. This paradigm resides on the notion of a closed infrastructure that resists the principles of a democra- tisation of knowledge (which is discussed in the subsequent chapter).

\section{Co-optation of OA by corporate publishers}

Publishers, especially the oligopoly of large forprofit institutions (Larivière et al., 2015), have been the first to co-opt OA and re-shape its purpose. The collective of these publishers successfully responded in a capitalist fashion to the reputation-making requirements of academia. That is, the practices of corporate publishing presuppose that academia in the Global North rests on the illusio of a market imperative such that all scholarly endeavours are to gain reputation and advertise its achievements through established publishing infrastructures. Scholars and especially research policy makers could have rejected corporate publishing by steering towards alternative approaches such as: open instead of proprietary publishing infrastructures, encouraging publishing that does not depend on authorship reputation, or allow for cost-effective green $O A$. These alternatives could have led the way for tackling a more general accessibility problem in academia as do the scholar-led publishers in a small-scaling fashion. Yet, where academia compromised on commercial solutions to the narrow accessibility problem, it also compromised negatively on working on rectifying accessibility in general.

The successful commodification of OA is visible in a variety of instances, one of which is the compromise made for embargo periods, outlined in 2007 as "a period of exclusivity for the publisher followed by free online access for the public" (Suber, 2007). In other words, the future OA article is paywalled for a fixed period until it is actually freely available. This mechanism essentially concedes that there is a right to economic exploitation on sides of the publishers, a period of about 12 to 24 months given for a future OA publication to be placed behind a paywall so that publishers may sustain revenue from subscriptions. It is here not coincidental that just those embargoed OA venues had in their times considerably higher citation rates (Laakso and Björk, 2013), which made them required subscription assets in libraries. This jeopardised positioning $\mathrm{OA}$ as a solution to the journal crisis in the first place (so 
that it could not even be claimed to be a solution to the affordability problem in this instance).

Alongside embargo periods, academia in the Global North accepted to invest in hybrid OA which is at the core of solidifying existing power structures in scholarly communication. Hybrid refers to the mechanism of keeping a journal published as a subscription journal while offering authors (or their institutions) to purchase an OA option for the individual article. This mechanism substantially subverted the idea of OA to a neoliberal ideology in which individuals can access $O A$ by means of considerable financial investment. The required fees outgrow those of any other form of OA making hybrid an excessively highly priced expenditure (Björk, 2012; Björk and Solomon, 2015; Khoo, 2018; Solomon and Björk, 2012). As of 2021, the Nature journal family issues the stunning price of $€ 9,500$ (US\$11,390, £8,290) for making an article OA (Else, 2020). Cell Press (held by Elsevier) charges $€ 8,500$ (US\$9,900, $£ 7,800$ ) for its name-giving flagship journal (Cell Press, 2021). This development is, even within financially well-equipped countries, ridiculing notions of democratisation. We may witness the usual counter-argument put forward by proponents of unfettered high-impact brands: the notion that all fields of scholarship offer alternative publication venues with much less expensive OA. This only highlights the blinkered attitude in the light of academia's illusio. Since academic career advances depend primarily on visibility and reputation, being published in a high-priced publication venue is desired above everything else. Consider in analogy an election where access to some polling places needs to be bought, but in return, votes in these places count twice. Sure, you can go for the less expensive contribution. But, without question, those who wish to make their voices heard will keep investing.

Next to the corporate repurposing of OA, commercialisations such as that of Knowledge Unlatched or the acquisition of OA publishing initiatives by publishing conglomerates (especially F1000Research by Taylor \& Francis and Hindawi by Wiley) show how fruitfully the efforts of bottom-up approaches turn into perpetuations of economic agendas: Knowledge Unlatched was launched as a not-for-profit institution and got stealthily integrated into a for-profit company, showing increased efforts to centralise and commercialise on the formerly communityfocussed infrastructure (Esposito, 2019; Gatti, 2018; Knöchelmann, 2018). Such switches to forprofit, either from within or by acquisition, show that these technological means are not in the hands of scholars who shape them. They are being integrated into an established order instead of being built collaboratively alongside new developments of culture principles which might help replication or distribution in the wake of an actual democratisation. The high-priced $O A$ is, likewise, building on the exploitation of academia's illusio, instead of trying to re-shape it. This shows that the narrow accessibility, though being somewhat open at the end of established discourse, remains or becomes exclusive at the end of being allowed to participate actively. This exclusivity becomes more apparent by looking at large-scale transformations.

\section{Large-scale transformations as narrow accessibility: Projekt DEAL}

The disproportionate costs associated with OA and the additional costs of the bureaucracy around organising $\mathrm{OA}$ led to the demand for large-scale OA deals. Among others, such deals are instituted in the Netherlands, Sweden, Norway, or Germany (Knöchelmann, 2020; Kwon, 2019; Max Planck Gesellschaft, 2019; de Rijcke, 2020). They are hailed as being transformative and ground-breaking. In detail, however, they are mostly a continuation of established practices.

The case of Germany is epitome in this regard: Projekt DEAL, representing a consortium of more than 700 libraries and research institutions in Germany, closed large-scale OA deals with both SpringerNature and Wiley, while discussions with Elsevier are ongoing (see for more details: Projekt $D E A L$, n.d.). Effectively, these deals are perpetuations of hybrid journal publishing in that German research institutions subscribe to read a publisher's entire non-OA journal portfolio while paying substantially to publish their articles OA. ${ }^{1}$ Through such deals, German scholars gain a considerable advantage compared with scholars in other countries in that they can, based on the contract and national financial backing, read the whole 
portfolio and publish OA without bureaucratic or financial hurdles. It is highly questionable whether other countries can afford to institute similar contracts. Likewise, it is unlikely that publishers will contemplate lowering the costs to publish hybrid, considering that such deals secure a safe revenue.

It follows that such deals are, on the one hand, segregating scholars and countries into those who can afford to publish OA, either by means of largescale deals or excessive publishing fees, or they are excluded from the benefits of OA. On the other hand, with a further increase of such OA publications, free access to them will create a two-class system, dividing journals and series internally. The affluent and financially well-equipped institutions and scholars can push their visibility further, while the rest must hope that others remain willing to subscribe to the journals publishing their paywalled scholarship. By enforcing such exclusivity in two respects, this is $\mathrm{OA}$ as a means of hegemony instead of a tool for breaking power. It reproduces the standing of a few by granting others (an excluded, periphery majority) the right to access their knowledge.

To be sure, there are non-fee OA venues; but the high-impact journals or book publishers demanded for career advancements in many fields remain paywalled or hybrid, ensuring that authors stay committed to the established hierarchy. Prominent institutions of this hierarchy regularly appeal for sympathy, such as EMBO (2019) or Nature Research (n.d.), putting forward the questionable argument that their high costs are justified because of the expensive selection processes and rejection rates. Precisely this, though, selectivity through rejection, maintains their positions in the hierarchy. In return, if the academy would agree to reshape its illusio and diminish the importance of reputation and hierarchy-that gamut of contingent postpublication impact based on pre-publication selection-this kind of business model would not survive. As long as this is not the case, investing in these publishers (paying their APCs or subscriptions) translates into investing into the perpetuation of the established hierarchy: these institutions do not gain their income because they are at the top of the impact gamut-they gain their income to maintain this impact gamut.

The national deals have further implications on the future of scholarship where today's narrow accessibility is traded against tomorrow's decision-making sovereignty in regard to digital infrastructures and system integration. In the context of the national OA deal in the Netherlands, for instance, making the works of Dutch scholars published in Elsevier journals freely available comes at the cost of providing the publishing corporation primary access to fostering their research intelligence service. In a market where rates of profit reached an unprecedented peak, this is a strategic positioning for future means of exploitation. With entering such a deal, a country concedes to support that business strategy which has long-term effects beyond mere cash-for-openness. Observe de Rijcke's (2020) reflections on this deal which "may effectively transfer crucial means to influence Dutch science policy to a monopolistic private enterprise". Future retrospections may well observe the realisation of a downward spiral in the context of such deals: they are solutions to an affordability problem that was exacerbated because of monopolistic market structures-and by actualising such solutions, those monopolistic market structures got carried into the future where renewed efforts were required to find solutions for an affordability problem. And so on. Note, here again, the exclusive position private entities as well as selected countries gain by means of large-scale deals about openness: the path towards open infrastructures is, thus, indifferent to being shaped by democratic means.

\section{Large-scale transformations as narrow accessibility: Plan S}

Plan S stands in line with these large-scale OA deals in that it fares as an embodiment of the progression of a neoliberal OA logic. The coalition of (predominantly, but not restricted to, the Global North) funding bodies was established in 2018 and its policy (or mandate) is in effect as of 2021. It requires all authors receiving funding from participating funding institutions to publish their results OA with particular conditions (Schiltz, 2018). These conditions have been widely debated with a diversity of voices in favour as well as 
against them. Conservative voices show concern about academic freedom in the wake of Plan S, since it might lead to reducing publishing options for authors as they have to choose a very liberal Creative Commons licence. This argument seems weak in light of what academic freedom may entail, especially that a scholar's freedom may be seen as more than the reinforcement of an individualist position in which some are active and others only passive participants. It may instead be seen as a member's right within a community so that a sense of solidarity is the fundament on which all participants tread in ways to allow all to be-de facto active-participants; a freedom implying constraints already by the acceptance of an other. But such dialectics is a delicate model and it seems to be rather absent in the heated debate on academic freedom. Whether or not it is coercion or freedom: Plan $S$ does not achieve to address issues of Global equality so that even progressive OA advocates show sympathies with the objections to Plan S (Moore, 2021). It is guided by a non-inclusive perspective, on a both disciplinary and Global level (Istratii and Demeter, 2020). Thus, though its objective to foster more openness may be laudable, the coalition's mode of implementing this openness is an enforcement of a form of an OA market. This enforcement and the resulting requirement to compete in a single $O A$ market may be the more pressing concerns that speak against Plan $S$ in the light of either freedom or equality.

In essence, Plan S perpetuates some of the principles of the large-scale deals, even though it aims to discredit hybrid OA: scholars supported by charitable or national funders in the Global North are provided the means to afford openness, while the bulk of other scholars is required to rely on individual deals or personal subsistence. All the while, the funded scholars can grant access to their knowledges to an unfunded other. It might be argued that the implementation of the mandate and the prolonged discussions preceding it might have resulted in some of the price hikes showcased in the preceding section. The high-impact journals are indeed pressured to make an OA option available to potential authors. That these journals are a costly business is not a matter of OA, though: the recent mandate only made the underlying prices beyond subscriptions visible. And recent submission numbers are revealing in the context of a geographic agenda setting: while the "mandate for immediate open access will apply to authors who produced only about $6 \%$ of the world's papers in 2017", "35\% of papers published in Nature and $31 \%$ of those in Science cited at least one coalition member as a funding source" (Brainard, 2021: 17). Plan S, thus, concerns only a fraction of all authors; all the while, high-impact journals need to address this fraction's needs disproportionately.

Exemplary for the neoliberal reasoning underpinning Plan $S$ is a talk given by Jean-Claude Burgelman who served as OA Envoy of the European Commission, which is responsible for the founding of Plan S. Speaking about the future of open science, he consistently suggests OA to be a key mechanism to advance returns on investments and to capitalise on the OA standing European countries already possess (Burgelman, 2020). In the same vein, Burgelman, among others, voiced the option of a "geo-specific access model" which would mean that OA would be restricted geographically (quoted in: McKie, 2019). The rationale is that this mechanism would pressure countries who have as yet not done so to invest in OA or related policies. And as long as they do not follow suit, these outsider countries should not benefit from the OA publications of European institutions, the reasoning goes.

Note that geo-specific and $O A$ are conceptually contradictory: if access to a publication is restricted geographically, it is an exclusive club good and not openly accessible. This may evoke a version of the notorious tax-payer argument of OA (Suber, 2003, 2016) which in this case might look as such: since countries in the EU are paying for the EU's research funding, they should benefit from the fruits of this funding, the reasoning of geo-specific goes. Though it may be claimed that this argument seems to be a powerful governance tool to enforce more openness in the short run and on the national level, it is particularly illustrative for the differences of accessibilities, or a redistribution/recognition divide in scholarly communication. On the one hand, it is based on a materialism that is easily misinterpreted as coercion and reputation within a country: scholars have to be forced 
to publish openly so that taxpayers may benefit from it; a beneficial by-product is the wider distribution and reputation-making potential for the country (as is visible, for instance, in the UK: Crossick, 2016; Finch, 2012). On the other hand, the argument neglects culture within a somewhat supranational scholarly endeavour. That is, it is indifferent to recognition and epistemic injustices of scholarly and scientific community as it builds on the premise that the production of knowledge is a fragmented endeavour of individual countries or scholars (which feeds back to the matter of solidarity in academic freedom). It eradicates the $O A$ reasoning in the debate of whether knowledge is a public good and, thus, contradicts its conceptual basis. If a country would want to be the sole beneficiary of its knowledge production, why not create a publishing platform to which only individuals in that country have free access? It seems ludicrous to pose this question. But then, what else as a patina of legitimacy is behind the logic of a geo-specific OA solution? It is certainly not an appeal to democratisation. Much rather, it is an appeal to the rule of reputation.

Speaking from the perspective of the Global South, Becerril-García critically comments on the development of Plan $S$ and argues that "a model is being set up which again makes the South and North confront each other, in lieu of seeking to construct common platforms that use technologies for preventing henceforth the possibility of simply being controlled" (Becerril-García, 2019. Precisely such assessments direct attention to the ideal of a democratisation of knowledge that is made impossible by solving a narrow accessibility problem. Yet, by claiming to solve an accessibility problem, the subjects pushing for the largescale OA discussed so far reinforce imperialist structures that are morally disguised: publishing $\mathrm{OA}$ is presented as a better publishing as, by so doing, the Global North grants others access to the results of their scholarship. In the following section, I turn to the problems of such a patronising notion.

\section{General accessibility: A democratisation of knowledge and epistemic injustices}

A democratisation of knowledge requires not just the dissemination of gratis knowledge, but holistic access to the means of communication, involving authorship, readership, and governance alike; a widening of accessibility to ongoing and future discourses in their making. Only problematising and solving this accessibility would bring about a democratisation of knowledge, which necessitates overcoming epistemic injustices. Accessibility, here, is a matter of recognition preceding redistribution. And in this sense, "questions of distributive justice are better understood in terms of normative categories that come from a sufficiently differentiated theory of recognition" (Honneth, 2003: 126). That which Honneth subsumes under the category of solidarity (1994: 208-210), or weness in the terminology of Alexander (2006: 43), is the recognition encountered in, and required for, the understanding of a democratisation of knowledge. Forms of epistemic injustice explain how such recognition is disturbed.

\section{A democratisation of knowledge}

The meaning of democratising knowledge is investigated in a variety of approaches (Biesta, 2007; Canagarajah, 2002; Dewey, [1927] 2012; Freire, [1970] 2017; Fuller, 2013; Ogone, 2017; Paasi, 2015; Pitts, 2017). It can be understood as the ways in which knowledge contributes to processes of democratisation and, in dialogue with this, how no individual shall be excluded from being able to know. This takes as its premise that knowledge is more than mere information or fact. Dewey ([1927] 2012: 137) argues that "knowledge is communication as well as understanding" but that

[d]issemination is something other than scattering at large. Seeds are sown, not by virtue of being thrown out at random, but by being so distributed as to take root and have a chance of growth (Dewey, [1927] 2012: 137).

Witness also how Trotter and Hodgkinson-Williams (2020: 346) ascribe both empowerment and breaking hegemonic statuses of knowledge systems to being able to "assert and define one's 
own understanding of what constitutes valuable knowledge". This expresses the requirement of not just consuming knowledge but gaining access to influencing what is being known. Having the ability to understand as well as the capacity to affect what, and how, something is known are equally crucial for the democratisation of knowledge which is, thereby, also related to being able to critique hegemonic orders. This is the case because knowledge is situated so that being a knower presupposes a social interdependence: "those who are not positioned well to influence epistemic resources will find that the dominant resources for knowing are less likely to be suited for knowing those parts of the world toward which their situatedness orients them" (Pohlhaus, 2011: 717). Issues of academic dependency (Alatas, 2003), intellectual imperialism (Alatas, 2000), or the neglect of "epistemic rights of marginal societies" (Ogone, 2017: 13) are likewise articulations of such issues of not being allowed substantial epistemic power. Underpinning the processes of knowing and, accordingly, the processes of producing and communicating knowledge, are themes of power and oppression that are captured by the concept of epistemic injustice.

Miranda Fricker developed a comprehensive concept and established two forms of epistemic injustice:

[t]estimonial injustice occurs when prejudice causes a hearer to give a deflated level of credibility to a speaker's word; hermeneutical injustice occurs at a prior stage, when a gap in collective interpretive resources puts someone at an unfair disadvantage when it comes to making sense of their social experiences (Fricker, 2007: 1).

The concept was further developed into more wide-ranging social epistemologies and also applied to a general discourse on knowledge (Fricker, 2017; Fuller, 2013) as well as cultural and intellectual imperialism (Alatas, 2000; Bhargava, 2013; McConkey, 2004; Medina, 2011, 2012; Ogone, 2017). Bhargava (2013: 413) calls epistemic injustice in this context a "colonization of the mind and intellectual cultures". Mboa Nkoudou (2020) works out the impact of $\mathrm{OA}$ as a driver of epistemic alienation, just as Albornoz et al. (2020) question whether open infrastructure may help achieve more epistemic justice. I build on these theoretical conceptions and concrete investigations, and propose a threefold conception of how oppression and marginalisation take place in scholarly communication:

\section{Testimonial injustice}

Firstly, testimonial injustice happens across disciplines in that groups of scholars are pre-emptively silenced. Paasi (2015) implies this in his conception of a Western hegemony that emerged as a power manifestation building on three forms of marginalisation: discrimination of scholars on grounds of their origin, exclusion based on the power of citations and evaluations of journals governed by Anglophone editorial boards (which is further connected to the marginalisation of languages other than English in scholarly communicationa trend non-native-English scholars within the Global North increasingly come to experience first-hand; see also: Gordin, 2017; Hyland, 2015), and, lastly, "the supposedly inferior quality of knowledge produced in non-Anglophone social spaces" (Paasi, 2015: 515).

By means of the unshakable entry thresholdclosed, pre-publication peer review-journals in the Global North hold power to the shibboleth to establishing knowledge: English language, specialised terminology, citation networks, and their modes of application in highly specialised discourse communities. The inequity produced through such testimonial injustice is the exclusion from discourses-one that occurs undeterred by economic or bureaucratic hindrances that a narrow accessibility OA may change, for this is not a readership access problem. In the historical development of the production of knowledge, this silencing recursively created, and continues to create today, more silencing by ignoring social groups in the conduct of discourses that are maintained by a Global North hegemony. That the legitimacy of produced knowledge hinges upon the apparatus surrounding its production is one of the truisms of academia in the Global North (see, for instance: Dewey, [1927] 2012; Latour, 1987; KnorrCetina, 1981). This includes an agenda setting and the ways of determining what is established knowledge: what are the methods, methodologies, conditions, and terminologies of correct 
and justified understanding, and what are the right places for this understanding to be disseminated with. This inherently has an exclusionary effect which is actualised by entry thresholds qua selection, foremost peer review and editorial decision-making. The resulting exclusion turns into oppression when it is no longer justifiable by a crude layperson/expert binary: non-Global North scholars are excluded from discourses despite being experts, for their expertise does not accord to norms of the Global North.

\section{Hermeneutical injustice}

Secondly, hermeneutical injustice takes place especially in scholarly fields of meaning-making since their epistemologies are highly socially context-dependent. Bear in mind that this form of injustice refers to cases where the experiences of some social groups in a collective are not reflected in and through interpretive schemes of that collective, for those social groups do not contribute to the collective's hermeneutical resources (Fricker, 2007; Medina, 2012). Medina (2017) even goes so far as to refer to hermeneutical death.

The imbalance of contributions and the resulting hermeneutical indifference disadvantages social groups culturally and materially. To be sure, this disadvantage hinges on the notion of the collective: in the context of an (aspired) global production of knowledge, the collective must comprise of all human subjects. Normatively, then, the drive towards globalisation marks the creation of a new collective that translates-epistemologically - to an inclusive expansion of hermeneutical resources. An exclusive expansion of a particular social group's interpretive schemes results in a hermeneutical oppression of those social groups which are included in the collective, but excluded from being contributors.

The arts and humanities as well as the humanistic social sciences aim to understand meaning by studying products of the human mind as well as the signs and symbols of meaningful human relations and actions (Beiner, 2009; Bod, 2013; Dilthey, [1883] 1922; Small, 2013). They, thus, aim to provide accounts and theories about being human and social or societal interdependence. Such accounts and theories, however, are always geared to just those products, relations, and actions studied. The resulting hermeneutical resources are effectively community efforts. The theories developed are tied towards communities in that the practices of developing them always depend on the particular forms of the social existing within this community at a specific moment in time. Some disciplines are more reflective of this - the philologies or historybut others are less so. Essentially, then, in the sense of a globalised production of knowledge, non-Global North scholars are treated unjust in that they contribute far less to global hermeneutic resources, or their modes of contribution are disturbed by the Northern-influenced global discourse. Moreover, especially within a Global North hegemony, clusters of epistemes are often artificially specialised and outsourced which renders their idiosyncrasies as another preemptively: race studies, indigenous studies, or gender studies are but a few examples here.

Consider how W.E.B. du Bois is side-lined among the founding figures of sociology or the way scholars of gender studies are continuously required to authorise their field beyond its scholarliness. The reason for the existence of the scholarly disciplines corresponding to these fields can both be internalised and externalised: the discursive realms exist so that their epistemes have a space for recognition and scholarly advancement on their own. The other reason for why they exist is grounded in the fact that they have not been recognised and advanced within an establishment of disciplines in the first place. The hermeneutic void that the established scholarship generated necessitated their disciplinary independence. All the while, their disciplinary existences remain to be ambiguous solutions that embody theirboth intellectually critical and politically nonaffirmative-struggles already in the processes of formation (see, for instance, Wendy Brown's (1997) deliberation about the intellectual project of women's studies).

Such hermeneutic void continues in a global scholarly context and its borders are marked by the binary of inclusion and exclusion of scholarly communication. Imagine a Great Library of Alexandria of the $21^{\text {st }}$ Century that strives to represent what it means to be human by collecting memoirs, myths, and meditations from around the world. If 
it consisted of, say, $90 \%$ of contributions from $10 \%$ of the world population, how representative of being human would it be?

\section{Epistemic objectification}

I issue a third category of injustice which is that of epistemic objectification: an exclusion by means of silencing the epistemic subject such that an individual (or social group) is treated as an informant while being undermined in her (or their) capacity of being an enquirer. The higher level of thinking is accorded only to one group-scholars in the Global North-while others remain to be mere objects, for their epistemic subjectivity is made structurally defective. Dotson (2012: 24) calls this epistemic exclusion "an infringement on the epistemic agency of knowers that reduces her or his ability to participate in a given epistemic community". This process is exemplified in a case Ogone communicates: the injustice that an African community has been objectified while being entirely excluded from the ensuing discourse and its benefits:

the Maasai people's genetic resources were 'harvested' without their informed consent [...]. The researchers are therefore guilty of conveniently keeping their subjects [turned objects] in unjust ignorance for their own selfish gains (Dotson, 2017: 24).

This intellectual imperialism can be summarised as a colonisation of information in that knowledge is drained from the World to circulate within discourses of the Global North and, first and foremost, make a benefit there.

\section{Discussion: Hegemonic openness and counter-hegemonic initiatives}

Solving a narrow accessibility problem does not change epistemic injustices. Quite the contrary, by maintaining hierarchies and the governance of the means of communication, OA solidifies injustices and disguises that imperial structures prevail and do harm. This argument is based on the premise that the production of knowledge becomes more globalised-and that this globalisation is, above all, an expansion of the Global North (or, in alternative terminology: a Westernisation).

\section{Reinforcement of hegemony}

Hegemony is reinforced by the impact of largescale OA. The journal as a "white epistemic institution" (Pohlhaus, 2017: 15) as well as the established book publishing venues keep their structural dominance by manifesting existing power structures in scholarly communication. They keep being governed by scholars of the Global North and their epistemes. Instead of an opening up of discourses - a globalisation in form of a global inclusion - the Global North governance causes an expansion of discourses to be an expansion of the dominance of the Global North that either excludes epistemes or demands the adjustment of other social groups to Western norms. Such an expansion is unreflective of the situatedness of knowledge in that it leads to epistemic adjustments to the norms of existing discourse practices of the Global North. Understanding and meaning, thus, loose parts of their specificity and contextual relevance for the community it was produced in and, originally, for.

Particularly for the assessment of large-scale $\mathrm{OA}$ implementations, the impact beyond the hegemonic order has not yet been acknowledged. The push of progressive neoliberal agendas through such implementations has a twofold impact. Firstly, these deals crystallise the way OA is perceived: as a costly endeavour that needs to be purchased and that many countries and institutions cannot afford. Underlying this is the cultural mediation of scholarly publishing: the broad investment into financially-heavy $O A$ manifests culture principles that portray openness as a good to be bought. Such culture principles contradict principles of democratisation that are based on solidarity instead of on commodification (just as the individualist conception of academic freedom). And secondly, they effect a furthering of market imperatives and a commodification of knowledge in that they imply an emphasis on competition which demands even more focus on league tables and rankings which are predominantly concerned with the Global North. Underlying this aspect is academia's illusio of the dominance of reputation, extended into a global domain. Neoliberal principles permeating academia allowed for an evaluative structuring that positions everything in relation to each other 
in rankings, lists, and units of reputation to be monitored (Brink, 2018; Dowsett, 2020; Moore et al., 2016). This has created an "academic nationalism" where the "claims for the need to internationalize national science are often made in the name of national competitiveness" (Paasi, 2015: 513).

It is this latter point that drives local producers of knowledge globally towards discourses of the Global North so that inequities are solidified in terms of epistemic injustices: scholars are more and more compelled to access means of communication of the Global North, for those count in league tables and rankings. Since large-scale OA developments correspond to such mechanisms, they are manifestations of this solidification. And yet, the task of accounting for the subtle but crucial differences of the drive of non-Global North scholars to Global North publishing venues, or of the latter trying to expand towards nonGlobal North scholars, is a delicate endeavour. Building inclusive infrastructures regionally is particularly at risk of replicating what Babini (2020: 338-339) calls the "traditional international scholarly communications system built in past decades, concentrated in 'mainstream' journals of the Global North and their evaluative indicators". If Projekt Deal or Plan S were to democratise knowledge, their enforcement of accessibility would have to account for the fact that their openness is a Global North expansion that risks the potential of democratisation of local projects on a truly_participatory_-global scale.

\section{Prevailing language issues}

The example of China further illustrates this: studies of the publishing behaviour of Chinese scholars and scientists are very much historical accounts of efforts of formal adaptation to the Global Northor North America and Western Europe-where for "most Chinese scientists [...] the gold standard is English-language journals" (Hvistendahl, 2013). Moreover, though China (like India or the United States) does not officially sign the plan, it now also endorses the general principles of Plan S (Brainard, 2021; Schiermeier, 2018), which supports their efforts for more national visibility in discourses of the Global North. The monetary reward system in China-where scholars publishing in high- impact journals are financially-rewarded-centres around visibility in the Global North-focussed Web of Science publishing index (Quan et al., 2017). Not coincidentally, native Chinese OA journals fail to attract high-impact research submissions, for they have low visibility in Global North publication indices (Shen, 2017). The technicalities of these shifts are easily accessible by means of indices and policies. The epistemic consequences, though, are rarely articulated.

The problem of missing multilingualism only feeds into the structural divides between the Global North and an inclusive idea of Globalisation (Salager-Meyer, 2008): in the UAE "the local language (Arabic) has been sidelined by English as the main language" where the publishing landscape is dominated by commercial publishers and fee-driven OA (Boufarss, 2020: 1712). Other studies provide similar evidence for a pressure to publish in venues of the Global North such as for India (Singh, 2018) or Chile (Broekhoff, 2019). Ogone (2017: 27) describes the futile aim for a balance as a "tendency for African scholars to seek validation from their Western counterparts while simultaneously trying to appeal to their African roots". Ultimately, indicative in this respect is that predatory publishing venues often target institutions outside of a Global North hegemony, especially Asia and Africa, to lure them into a false international visibility (Berger, 2017; Gasparyan et al., 2016; Omobowale et al., 2014; Shen and Björk, 2015). That the OA initiatives discussed above manifest existing hierarchies and, thus, the corresponding mechanisms of reputation and scholarly meaning-making shows that tackling such issues of language and uptake of local OA venues outside the Global North is not of interest. The claims of a democratisation cannot justifiably be made here, since we see much more of a sharing of the rich with the poor than a balanced, mutual sharing.

\section{The counter-hegemonic impact of small- scaling}

It should not be left unacknowledged that there are indeed ways the global sharing of knowledge produced in the Global North can be beneficial for all, and that there are institutions successfully acting against the hegemonic order. Firstly, 
where knowledge-especially directly appliable knowledge such as from STEM or medical science fields-is made available globally for free, this can have an undeniable positive effect in the short run. Initiatives such as Hinari, research4life, AGORA, or OARE aim for global access to knowledge as a bridge to increase the viability of humanitarian efforts. Yet, short term is the keyword here: these initiatives need to be separated from the OA that is pushed for in academia in the Global North. The humanitarian efforts seek short term solutions put forward to solve crises today. Progressive neoliberalism puts $\mathrm{OA}$ forward as a solution that aims to keep the established order in the long run.

Secondly, as already mentioned, there are initiatives highlighting that a different $O A$ is possible, one that is bottom-up driven, tied to communities, and conceiving of accessibility in a more democratic way. Sharing knowledge is bound to the notion of solidarity here; neither to taxes nor reward. It is this approach to openness, as Joy forcefully puts it, that means "taking back from commercial publishers the full reins of the means of production of academic publishing and reinventing the academic press as a critical arm of both the research and teaching mission of the University" (Joy, 2020: 324).

I may refer to initiatives such as the smallscaling publishers united in the Radical Open Access Collective or the Open Library of Humanities. Its institutional philosophies are based on collaboration, co-ownership, and the focus on scholarly communities just as Moore (2019: 129) explicates: "[s]cholar-led publishers are embedded in their disciplinary networks, reflecting a nuanced publishing praxis that is sensitive to the working practices of particular scholarly communities", allowing for initiatives to be experimental and "emancipatory from the assumptions and structures of traditional publishing" (Moore, 2019: 130). To be sure, as these initiatives originate in Global North scholarship, being tied to this scholarship does not make them in any way nonGlobal North. But they invite replication, create open infrastructures to be re-used globally, and showcase that governance of the means of communication can be democratised. They, thus, provide points of reference for both cultural and material change. In fact, since these initiatives are small-scaling-achieving their potential by many small community-owned initiatives (Barnes and Gatti, 2019)—-their success does not depend on the uptake of those publishing initiatives already within the network, but on replication. Since this is the case, these initiatives may as yet seem to be weak in their implementation and have only little structural effect compared with the shift towards large-scale implementations of OA. Moreover, by bypassing established publishing structures entirely, it can be argued that their efforts are not about $O A$ at all, but about a radically new version of collaborative publishing more generally. Precisely this, uptake through collaborative replication, may mark their potential for a different future that claims power as a diversity of bottom-up initiatives in the sense of Wright's eroding of the established system: building "more democratic, egalitarian, participatory economic relations where possible in the spaces and cracks within this complex system" (Wright, 2019: 60).

Furthermore, this category needs to account for initiatives already going a different way such as AmeliCA or Redalyc which achieve a democratic accessibility, allowing for community-owned processes and open publishing without author charges. Governance of the means of communication is spread across scholarly communities here. Especially these are important as counterparts to Plan S: in the end, investments in large-scale $\mathrm{OA}$ deals and Plan $S$ could have likewise been investments in European imitations of such South American initiatives. Initiatives focussing on the minutiae of, for instance, intellectual property rights (Beer and Oguamanam, 2014) or the governance and local applicability of open data infrastructures (Bonina et al., 2020) are likewise vital for the success of a democratisation of knowledge, particularly if they do not simply put up technological means but accompany a corresponding culture change as well.

\section{Conclusion: The reciprocity of technology and culture}

"The solution is not to 'integrate' [the oppressed] into the structure of oppression, but to transform that structure so that [the oppressed] can become 'beings for themselves'"' (Freire, [1970] 2017: 47). 
What Freire suggests as a solution to the banking concept of education is precisely what OA does not achieve with its large-scale manifestations in academia in the Global North: fundamentally transform its communicative power structure so that epistemic injustices can be overcome. This is what I explicated in this article.

I provided the argument that the hegemonic accessibility problem is short-sighted and that, by pushing for such OA, established subjects in academia in the Global North are not interested in democratising knowledge but seek to retain owning the governance of the means of communication. I showcased dominant solutions to this accessibility problem, culminating in a critique of the current large-scale implementations of OA in light of an ideal to democratise knowledge. The development of a deeper understanding of epistemic injustices helps apprehending the shortcoming of the narrow accessibility problem. This approach to openness solidifies the powers inherent in the established means of scholarly communication and, thus, reproduces existing inequities. It reinstitutes that large parts of the means of communication remain within a Global North hegemony, despite all counter-efforts of small-scaling, community-centred publishing initiatives. Moreover, and highly problematic regarding the normative statements of $O A$ being a better publishing, these practices of OA disguise that the existing inequities prevail and that the cultural orders of knowledge embodied by practices have not changed: knowledge produced by the Global North is deemed superior.

Conclusively, this diagnosis positions OA next to other technologies that promised more equity but could not deliver on this promise. Early conceptions of revolutionary change are often driven by a technological determinism: Marx's historical materialism provides a reductionist account as do premises in McLuhan's media analyses. Up until today, new technology is often welcomed as transformative in that it is said to allow for a restructuring of established power relations. Materialist conceptions focus on redistributional mechanisms and neglect cultural aspects and a preceding conception of recognition that are significant for making such redistribution necessary in the first place. Technology is not fully conceptualised if the culture it is rooted in as well as its governance and entrenched hierarchies are ignored. Above all, the history of the internet is one such example where neutrallynetworked machines could have provided a level playing field (Morozov, 2011, 2013). Today, however, it is but a replica of the hegemony as it has existed before the establishment of HTML. The Dark Web is the anarchic manifestation sidelining the establishment just as SciHub does for academia. And at least in academia, such anarchy will stay as a solution until better alternatives are established on a broader scale. Similarly, OA in its large-scale, commodified formation in the Global North, was not able to take advantage of the redistributional potential of new media technologies, resulting in the replication of old hierarchies, since it did not build on an improved notion of recognition. Successful change through technology is contingent on the problem that it is set to solve: the problem of accessibility is posed in a way that allows for OA to being only a cosmetic shift within existing epistemic hierarchies, without posing significant change to these hierarchies themselves. We need to look at culture principles just as we go along establishing technological means.

\section{Acknowledgements}

I would like to thank Emmanuella Asabor, Vanessa Bittner, Patrice Collins, Demar Lewis, Chloe Sariego, Philip Smith, and Anne Taylor, all at Yale University, for their helpful feedback on earlier drafts of this article. Thanks also to three unknown reviewers as well as the editors of Science \& Technology Studies who all provided valuable feedback. I would also like to thank the London Arts and Humanities Partnership, the Arts and Humanities Research Council, and the Studienstiftung des Deutschen Volkes for supporting my scholarship. 


\section{References}

Adema J and Moore SA (2018) Collectivity and collaboration: imagining new forms of communality to create resilience in scholar-led publishing. Insights: the UKSG journal 31(3). DOI: 10.1629/uksg.399.

Aguado-López E and Becerril-Garcia A (2019) AmeliCA before Plan S - The Latin American Initiative to develop a cooperative, non-commercial, academic led, system of scholarly communication. LSE Impact of Social Sciences Blog. Available at: https://blogs.Ise.ac.uk/impactofsocialsciences/2019/08/08/amelica-before-plan-s-the-latin-american-initiative-to-develop-a-cooperative-non-commercial-academicled-system-of-scholarly-communication/ (accessed 30 January 2020).

Alatas SF (2003) Academic Dependency and the Global Division of Labour in the Social Sciences. Current Sociology 51(6): 599-613. DOI: 10.1177/00113921030516003.

Alatas SH (2000) Intellectual Imperialism: Definition, Traits, and Problems. Asian Journal of Social Science 28(1): 23-45. DOI: 10.1163/030382400X00154.

Albornoz D, Okune A and Chan L (2020) Can Open Scholarly Practices Redress Epistemic Injustice? In: Eve MP and Gray J (eds) Reassembling Scholarly Communications: Histories, infrastructures, and global politics of open access. Cambridge, MA: The MIT Press, pp. 65-79.

Alexander JC (2005) Why Cultural Sociology Is Not 'Idealist'. Theory, Culture \& Society 22(6): 19-29. DOI: $10.1177 / 0263276405059412$.

Alexander JC (2006) The civil sphere. Oxford, UK: Oxford University Press.

Alexander JC and Smith P (2001) The Strong Program in Cultural Theory: Elements of a Structural Hermeneutics. In: Turner JH (ed) Handbook of sociological theory: New York, NY: Springer, pp. 135-150.

Anderson P (1976) The Antinomies of Antonio Gramsci. New Left Review (100).

Andrews N and Okpanachi E (2012) Trends of Epistemic Oppression and Academic Dependency in Africa's Development: The Need for a New Intellectual Path. The Journal of Pan-African Studies 5(8): 85-104.

Babini D (2020) Toward a Global Open-Access Scholarly Communications System: A Developing Region Perspective. In: Eve MP and Gray J (eds) Reassembling Scholarly Communications: Histories, infrastructures, and global politics of open access. Cambridge, MA: The MIT Press, pp. 331-339.

Bacevic J and Muellerleile C (2017) The moral economy of open access. European Journal of Social Theory 21(2): 169-188. DOI: 10.1177/1368431017717368.

Barnes L (2018) Ten Years of OBP: An Interview with Alessandra Tosi and Rupert Gatti (Part One). Open Book Publishers Blog. Available at: https://doi.org/10.11647/OBP.0173.0082 (accessed 9 January 2021).

Barnes L and Gatti R (2019) Bibliodiversity in Practice: Developing Community-Owned, Open Infrastructures to Unleash Open Access Publishing. In: ELPUB 2019 23d International Conference on Electronic Publishing: OpenEdition Press.

Becerril-García A (2019) AmeliCA vs Plan S: Same target, two different strategies to achieve Open Access. Available at: http://amelica.org/index.php/en/2019/02/10/amelica-vs-plan-s-same-target-two-differentstrategies-to-achieve-open-access/ (accessed 3 April 2020).

Beer J de and Oguamanam C (2014) Open Minds: Lessons from Nigeria on Intellectual Property, Innovation, and Development. In: Smith ML and Reilly KMA (eds) Open development: Networked innovations in international development. Cambridge, MA: The MIT Press, pp. 275-296.

Beiner M (2009) Humanities: Was Geisteswissenschaft macht. Und was sie ausmacht. Berlin: Berlin University Press.

Berger M (2017) Everything You Ever Wanted to Know About Predatory Publishing but Were Afraid to Ask. CUNY Academic Works. Available at: https://academicworks.cuny.edu/ny_pubs/141 (accessed 13 July 2020). 
Berlin (2003) Berlin Declaration. Available at: https://openaccess.mpg.de/Berlin-Declaration (accessed 24 May 2019).

Bethesda (2003) Bethesda Statement on Open Access Publishing. Available at: http://legacy.earlham. edu/ peters/fos/bethesda.htm (accessed 25 January 2020).

Bhargava R (2013) Overcoming the Epistemic Injustice of Colonialism. Global Policy 4(4): 413-417. DOI: 10.1111/1758-5899.12093.

Biesta G (2007) Towards the knowledge democracy? Knowledge production and the civic role of the university. Studies in Philosophy and Education 26(5): 467-479. DOI: 10.1007/s11217-007-9056-0.

Björk B-C (2012) The hybrid model for open access publication of scholarly articles: A failed experiment? Journal of the American Society for Information Science and Technology 63(8): 1496-1504. DOI: 10.1002/ asi.22709.

Björk B-C and Solomon D (2015) Article processing charges in OA journals: relationship between price and quality. Scientometrics 103(2): 373-385. DOI: 10.1007/s11192-015-1556-z.

Bod R (2013) A New History of the Humanities. Oxford, UK: Oxford University Press.

Bonina C and Scrollini F (2020) Governing Open Health Data in Latin America. In: Smith ML and Seward RK (eds) Making open development inclusive: Lessons from IDRC research. Cambridge, MA: The MIT Press, pp. 291-316.

Bosman J and Kramer B (2018) Open access levels: a quantitative exploration using Web of Science and oaDOI data. PeerJ. DOI: 10.7287/peerj.preprints.3520v1.

Boufarss M (2020) Charting the Open Access scholarly journals landscape in the UAE. Scientometrics. DOI: 10.1007/s11192-020-03349-0.

Bourdieu P (1998) Practical reason: On the theory of action. Stanford, CA: Stanford University Press.

Bowman ND and Keene JR (2018) A Layered Framework for Considering Open Science Practices. Communication Research Reports 35(4): 363-372. DOI: 10.1080/08824096.2018.1513273.

Brainard J (2021) Open access takes flight. Science 371(6524): 16-20. DOI: 10.1126/science.371.6524.16.

Brehm E and Neumann J (2018) Anforderungen an Open-Access-Publikation von Forschungsdaten: Empfehlungen für einen offenen Umgang mit Forschungsdaten. o-bib. Das offene Bibliotheksjournal 5(3). DOI: 10.5282/O-BIB/2018H3S1-16.

Brembs B (2018) Prestigious Science Journals Struggle to Reach Even Average Reliability. Frontiers in human neuroscience. DOI: 10.3389/fnhum.2018.00037.

Brembs B, Button KS and Munafò M (2013) Deep impact: unintended consequences of journal rank. Frontiers in human neuroscience. DOI: 10.3389/fnhum.2013.00291.

Brink C (2018) The soul of a university: Why excellence is not enough. Bristol, UK: Bristol University Press.

Broekhoff (2019) Perceived Challenges to Anglophone Publication at Three Universities in Chile. Publications 7(4): 1-20. DOI: 10.3390/publications7040061.

Brown W (1997) The impossibility of women's studies. differences: A Journal of Feminist Cultural Studies 9(3): 79-101.

Budapest (2002) Budapest Open Access Initiative. Available at: https://www.budapestopenaccessinitiative. org/read (accessed 25 January 2020).

Burgelman J-C (2020) Open science and open scholarship: Will Europe lead the change...? Keynote at Academic Publishing Europe 2020. Available at: https://www.linkedin.com/embed/feed/update/urn:li:u gcPost:6622871508429742080 (accessed 23 January 2020).

Canagarajah AS (2002) A geopolitics of academic writing. Pittsburgh, PA: University of Pittsburgh Press. 
Cell Press (2021) Rights, sharing, and embargo policies. Available at: https://www.cell.com/rights-sharingembargoes (accessed 9 February 2021).

Chan L and Gray E (2020) Centering the Knowledge Peripheries through Open Access: Implications for Future Research and Discourse on Knowledge for Development. In: Eve MP and Gray J (eds) Reassembling Scholarly Communications: Histories, infrastructures, and global politics of open access. Cambridge, MA: The MIT Press, pp. 197-222.

Crossick G (2016) Monographs and open access. Insights: the UKSG journal 29(1). DOI: 10.1629/uksg.280.

de Rijcke S (2020) Elsevier and the Dutch Open Science goals. Available at: https://leidenmadtrics.nl/ articles/s-de-rijcke-cwts-leidenuniv-nl (accessed 20 May 2020).

de Sousa Santos B (2016) Epistemologies of the South and the future. From the European South (1): 17-29.

Dewey J ([1927] 2012) The Public and Its Problems: An Essay in Political Inquiry. University Park, PA: Penn State University Press.

Dilthey W ([1883] 1922) Einleitung in die Geisteswissenschaften: Versuch einer Grundlegung für das Studium der Gesellschaft und ihrer Geschichte. Leipzig, Berlin: B.G. Teubner.

Dirlik A (2007) Global South: Predicament and Promise. The Global South 1(1): 12-23.

Dotson K (2012) A Cautionary Tale: On Limiting Epistemic Oppression. Frontiers: A Journal of Women Studies 33(1): 24. DOI: 10.5250/fronjwomestud.33.1.0024.

Dowsett L (2020) Global university rankings and strategic planning: a case study of Australian institutional performance. Journal of Higher Education Policy and Management 13(1): 1-17. DOI: 10.1080/1360080X.2019.1701853.

Else H (2020) Nature journals reveal terms of landmark open-access option. Nature 588(7836): 19-20. DOI: 10.1038/d41586-020-03324-y.

Embo (2019) The publishing costs at EMBO. Available at: https://www.embo.org/news/articles/2019/thepublishing-costs-at-embo (accessed 5 May 2020).

Emirbayer M (2004) The Alexander School of Cultural Sociology. Thesis Eleven 79(1): 5-15. DOI: $10.1177 / 0725513604046951$.

Esposito J (2019) Internal Contradictions with Open Access Books. The Scholarly Kitchen. Available at: https:// scholarlykitchen.sspnet.org/2019/06/04/internal-contradictions-with-open-access-books/ (accessed 26 January 2020).

Eve MP and Gray J (eds) (2020) Reassembling Scholarly Communications: Histories, infrastructures, and global politics of open access. Cambridge, MA: The MIT Press.

Eve MP, Inglis K, Prosser D, Speicher L and Stone G (2017) Cost estimates of an open access mandate for monographs in the UK's third Research Excellence Framework. Insights: the UKSG journal 30(3): 89-102. DOI: $10.1629 /$ uksg.392.

Eysenbach G (2006) Citation Advantage of Open Access Articles. PLOS Biology 4(5). DOI: 10.1371/journal. pbio.0040157.

Finch J (2012) Accessibility, sustainability, excellence: how to expand access to research publications: Report of the Working Group on Expanding Access to Published Research Findings. Available at: https://www. acu.ac.uk/research-information-network/finch-report-final (accessed 12 December 2018).

Flyvbjerg B (2006) Five Misunderstandings About Case-Study Research. Qualitative Inquiry 12(2): 219-245. DOI: $10.1177 / 1077800405284363$.

Fraser N (2019) The Old Is Dying and the New Cannot Be Born: From Progressive Neoliberalism to Trump and Beyond. London, UK: Verso. 
Fraser N and Honneth A (eds) (2003) Redistribution or recognition? A political-philosophical exchange. London, UK: Verso.

Freire P ([1970] 2017) Pedagogy of the oppressed. London, UK: Penguin Books.

Fricker M (2007) Epistemic injustice: Power and the ethics of knowing. Oxford, UK: Oxford University Press.

Fricker M (2017) Evolving concepts of epistemic injustice. In: Kidd IJ, Medina J and Pohlhaus G (eds) The Routledge Handbook of Epistemic Injustice: London: Routledge, pp. 53-60.

Fuchs C (2020) Communication and Capitalism: A Critical Theory. London, UK: University of Westminster Press.

Fuller S (2013) The Knowledge Book: Key Concepts in Philosophy, Science and Culture. Cambridge, UK: Cambridge University Press.

Gartman D (2007) The strength of weak programs in cultural sociology: A critique of Alexander's critique of Bourdieu. Theory and Society 36(5): 381-413. DOI: 10.1007/s11186-007-9038-9.

Gasparyan AY, Nurmashev B, Voronov AA, Gerasimov AN, Koroleva AM and Kitas GD (2016) The Pressure to Publish More and the Scope of Predatory Publishing Activities. Journal of Korean medical science 31(12): 1874-1878. DOI: 10.3346/jkms.2016.31.12.1874.

Gatti OR (2018) Why OBP is not participating in KU Open Funding: and why libraries should understand the reasons. Available at: https://blogs.openbookpublishers.com/why-obp-is-not-participating-in-ku-openfunding-and-why-libraries-should-understand-the-reasons/ (accessed 26 January 2020).

Gordin MD (2017) Scientific Babel: The language of science from the fall of Latin to the rise of English. London, UK: Profile Books.

Gramsci A (1992) Prison notebooks: volume 1. New York, NY: Columbia University Press.

Gramsci A (1996) Prison notebooks: volume 2. New York, NY: Columbia University Press.

Hall S (1986) The Problem of Ideology: Marxism without Guarantees. Journal of Communication Inquiry 10(2): 28-44. DOI: 10.1177/019685998601000203.

Hess C (2012) The Unfolding of the Knowledge Commons. St. Anthony's International Review: 13-24.

Hess C and Ostrom E (eds) (2011) Understanding knowledge as a commons: From theory to practice. Cambridge, MA: MIT Press.

Holbrook B (2019) Philosopher's Corner: Open Science, Open Access, and the Democratization of Knowledge. Issues in Science and Technology 35(3): 26-28.

Honneth A (1994) Kampf um Anerkennung: Zur moralischen Grammatik sozialer Konflikte. Frankfurt am Main: Suhrkamp.

Honneth A (2003) Redistribution as Recognition. In: Fraser N and Honneth A (eds) Redistribution or recognition? A political-philosophical exchange. London, UK: Verso, pp. 110-197.

Hvistendahl M (2013) China's publication bazaar. Science 342(6162): 1035-1039. DOI: 10.1126/ science.342.6162.1035.

Hyland K (2015) Academic publishing: Issues and challenges in the construction of knowledge. Oxford, UK: Oxford University Press.

Inefuku HW (2017) Globalization, Open Access, and the Democratization of Knowledge. Educause Review 52(4).

Istratii R and Demeter M (2020) Plan S and the 'opening up' of scientific knowledge: A critical commentary. Decolonial Subversions: 13-21.

Joy EA (2020) Not Self-Indulgence, but Self-Preservation: Open Access and the Ethics of Care. In: Eve MP and Gray J (eds) Reassembling Scholarly Communications: Histories, infrastructures, and global politics of open access. Cambridge, MA:The MIT Press, pp. 317-329. 
Khoo SY-S (2018) Article Processing Charge Hyperinflation and Price Insensitivity: An Open Access Sequel to the Serials Crisis. LIBER Quarterly 29(1): 1. DOI: 10.18352/lq.10280.

Knobloch J, Albiez EJ and Schmitz H (1982) A serological survey on viral haemorrhagic fevers in liberia. Annales de I'Institut Pasteur / Virologie 133(2): 125-128. DOI: 10.1016/S0769-2617(82)80028-2.

Knoche M (2019) Kritik der politischen Ökonomie der Wissenschaftskommunikation als Ideologiekritik: Open Access. In: Krüger U and Sevignani S (eds) Ideologie, Kritik, Öffentlichkeit: Verhandlungen des Netzwerks Kritische Kommunikationswissenschaft: Leipzig: Leipzig University, pp. 140-174.

Knöchelmann M (2018) Knowledge Unlatched, failed transparency, and the commercialisation of open access book publishing. LSE Impact of Social Sciences Blog. Available at: https://blogs.lse.ac.uk/impactofsocialsciences/2018/10/03/knowledge-unlatched-failed-transparency-and-the-commercialisation-of-openaccess-book-publishing/ (accessed 26 January 2020).

Knöchelmann M (2019a) Open Science in the Humanities, or: Open Humanities? Publications 7(4): 1-17 DOI: 10.3390/publications7040065.

Knöchelmann M (2019b) Pay to Publish Open Access: On the DEAL-Wiley Agreement. Elephant in the Lab. Available at: https://doi.org/10.5281/zenodo.2545583 (accessed 13 July 2020).

Knöchelmann M (2020) Systemimmanenz und Transformation: Die Bibliothek der Zukunft als lokale Verwalterin? Preprint version. Bibliothek Forschung und Praxis. DOI: 10.18452/22107.

Knorr-Cetina KD (1981) The Manufacture of Knowledge: An Essay on the Constructivist and Contextual Nature of Science. Oxford, UK: Pergamon.

Kulczycki E, Engels TCE, Pölönen J, et al. (2018) Publication patterns in the social sciences and humanities: evidence from eight European countries. Scientometrics 116(1): 463-486. DOI: 10.1007/s11192-0182711-0.

Kwon D (2019) Elsevier Progresses in Open-Access Deal Making. Available at: http://www.mynewsdesk.com/ se/kungliga_biblioteket/pressreleases/new-transformative-agreement-with-elsevier-enables-unlimitedopen-access-to-swedish-research-2946642 (accessed 26 January 2020).

Laakso M and Björk B-C (2013) Delayed open access: An overlooked high-impact category of openly available scientific literature. Journal of the American Society for Information Science and Technology 64(7): 1323-1329. DOI: 10.1002/asi.22856.

Lander E (2000) Eurocentrism and Colonialism in Latin American Social Thought. Nepantla: Views from South 1(3): 519-532.

Lariviere $V$ and Sugimoto CR (2018) The Journal Impact Factor: A brief history, critique, and discussion of adverse effects. ArXiv. Available at: https://arxiv.org/pdf/1801.08992 (accessed 2 July 2019).

Larivière V, Haustein S and Mongeon P (2015) The Oligopoly of Academic Publishers in the Digital Era. PloS one 10(6). DOI: 10.1371/journal.pone.0127502.

Latour B (1987) Science in action: How to follow scientists and engineers through society. Cambridge, MA: Harvard University Press.

Latour B (1993) We have never been modern. Cambridge, MA: Harvard University Press.

Longino HE (2002) The fate of knowledge. Princeton, NJ: Princeton University Press.

Luczaj K (2020) Conceptualising the academic periphery: The case of Eastern European academic systems. Globalisation, Societies and Education 18(5): 511-527. DOI: 10.1080/14767724.2020.1789450.

Martín-Martín A, Costas R, van Leeuwen T and Delgado López-Cózara E (2018) Evidence of open access of scientific publications in Google Scholar: A large-scale analysis. Journal of Informetrics 12(3): 819-841. DOI: 10.1016/j.joi.2018.06.012. 
Max Planck Gesellschaft (2019) Projekt Deal and Springer Nature reach understanding on world's largest transformative open access agreement. Available at: https://www.mpg.de/13823733/projekt-dealspringer-nature-open-access-agreement (accessed 26 January 2020).

Mboa Nkoudou TH (2020) Epistemic Alienation in African Scholarly Communications: Open Access as a Pharmakon. In: Eve MP and Gray J (eds) Reassembling Scholarly Communications: Histories, infrastructures, and global politics of open access. Cambridge, MA: The MIT Press, pp. 25-40.

McConkey J (2004) Knowledge and Acknowledgement: 'Epistemic Injustice' as a Problem of Recognition. Politics 24(3): 198-205. DOI: 10.1111/j.1467-9256.2004.00220.x.

McKie A (2019) 'Location-specific' blocks on journal access could be OA 'interim solution'. Times Higher Education. Available at: https://www.timeshighereducation.com/news/location-specific-blocks-journalaccess-could-be-oa-interim-solution (accessed 23 January 2020).

McKiernan EC, Schimanski LA, Nieves CM, Matthias L, Niles M and Alperin JP (2019) Use of the Journal Impact Factor in academic review, promotion, and tenure evaluations. PeerJ Preprints. DOI: 10.7287/peerj. preprints.27638v2.

Medina J (2011) The Relevance of Credibility Excess in a Proportional View of Epistemic Injustice: Differential Epistemic Authority and the Social Imaginary. Social Epistemology 25(1): 15-35. DOI: 10.1080/02691728.2010.534568.

Medina J (2012) Hermeneutical Injustice and Polyphonic Contextualism: Social Silences and Shared Hermeneutical Responsibilities. Social Epistemology 26(2): 201-220. DOI: 10.1080/02691728.2011.652214.

Medina J (2017) Varieties of hermeneutical injustice. In: Kidd IJ, Medina J and Pohlhaus G (eds) The Routledge Handbook of Epistemic Injustice: London, UK: Routledge, pp. 41-52.

Monteiro K and Hirano E (2020) A periphery inside a semi-periphery: The uneven participation of Brazilian scholars in the international community. English for Specific Purposes 58: 15-29. DOI: 10.1016/j. esp.2019.11.001.

Moore S (2019) Common Struggles: Policy-based vs. scholar-led approaches to open access in the humanities. Humanities Commons. Doctoral Dissertation, King's College London. Available at: http://dx.doi. org/10.17613/st5m-cx33 (accessed 1 April 2020).

Moore S (2021) Open Access, Plan S and 'Radically Liberatory' Forms of Academic Freedom. Development and Change. DOI: 10.1111/dech.12640.

Moore S, Neylon C, Eve MP, O'Donnell DP and Pattinson D (2016) "Excellence R Us": university research and the fetishisation of excellence. Palgrave Communications 3: 1-13. DOI: 10.1057/palcomms.2016.105.

Morozov E (2011) The net delusion: The dark side of internet freedom. New York, NY: Public Affairs.

Morozov E (2013) To save everything, click here: The folly of technological solutionism. New York, NY: PublicAffairs.

Münch R (2007) Die akademische Elite: Zur sozialen Konstruktion wissenschaftlicher Exzellenz. Frankfurt am Main: Suhrkamp.

Münch R (2011) Akademischer Kapitalismus: Zur politischen Ökonomie der Hochschulreform. Berlin: Suhrkamp.

Nature Research (n.d.) Open access at the Nature Portfolio. Available at: https://www.nature.com/natureresearch/open-access (accessed 19 January 2021).

Ogone JO (2017) Epistemic Injustice: African Knowledge and Scholarship in the Global Context. In: Bartels A, Eckstein L, Waller N and Wiemann D (eds) Postcolonial justice: Leiden: Brill, pp. 17-36.

Okune A (2020) Open Ethnographic Archiving as Feminist, Decolonizing Practice. Catalyst 6(2): 1-37. DOI: 10.28968/cftt.v6i2.33041. 
Omobowale AO, Akanle O, Adeniran Al and Kameorudeen A (2014) Peripheral scholarship and the context of foreign paid publishing in Nigeria. Current Sociology 62(5): 666-684.

Paasi A (2015) Academic Capitalism and the Geopolitics of Knowledge. In: Secor AJ, Agnew JA, Sharp JP and Mamadouh V (eds) The Wiley Blackwell companion to political geography: Oxford, UK: John Wiley \& Sons, pp. 509-523.

Pitts AJ (2017) Decolonial praxis and epistemic injustice. In: Kidd IJ, Medina J and Pohlhaus G (eds) The Routledge Handbook of Epistemic Injustice: London, UK: Routledge, pp. 149-157.

Pohlhaus G (2011) Relational Knowing and Epistemic Injustice: Toward a Theory of Willful Hermeneutical Ignorance. Hypatia 27(4): 715-735. DOI: 10.1111/j.1527-2001.2011.01222.x.

Pohlhaus G (2017) Varieties of epistemic injustice. In: Kidd IJ, Medina J and Pohlhaus G (eds) The Routledge Handbook of Epistemic Injustice: London: Routledge, pp. 13-26.

Posada A and Chen G (2018) Inequality in Knowledge Production: The Integration of Academic Infrastructure by Big Publishers. ELPUB 2018. Available at: https://elpub.episciences.org/4618/pdf.

Projekt DEAL (n.d.) Über Projekt DEAL - Projekt DEAL. Available at: https://www.projekt-deal.de/aktuelles/ (accessed 23 May 2020).

Projekt DEAL (2019) Wiley Contract. Available at: https://www.projekt-deal.de/wiley-contract/ (accessed 27 January 2020).

Quan W, Chen B and Shu F (2017) Publish or impoverish. Aslib Journal of Information Management 69(5): 486-502. DOI: 10.1108/AJIM-01-2017-0014.

Rodriguez Medina L (2015) Centers and peripheries in knowledge production. London, UK: Routledge.

Salager-Meyer F (2008) Scientific publishing in developing countries: Challenges for the future. Journal of English for Academic Purposes 7(2): 121-132. DOI: 10.1016/j.jeap.2008.03.009.

Schiermeier Q (2018) China backs bold plan to tear down journal paywalls. Nature 564(7735): 171-172. DOI: 10.1038/d41586-018-07659-5.

Schiltz M (2018) Science Without Publication Paywalls: cOAlition S for the Realisation of Full and Immediate Open Access. Frontiers in Neuroscience 12. DOI: 10.3389/fnins.2018.00656.

Sen A (1999) Development as freedom. Oxford, UK: Oxford University Press.

Sengupta P (2021) Open access publication: Academic colonialism or knowledge philanthropy? Geoforum 118: 203-206. DOI: 10.1016/j.geoforum.2020.04.001.

Shen C (2017) Open Access Scholarly Journal Publishing in Chinese. Publications 5(4): 1-17. DOI: 10.3390/ publications5040022.

Shen C and Björk B-C (2015) 'Predatory' open access: a longitudinal study of article volumes and market characteristics. BMC Medicine 13(1): 1-15. DOI: 10.1186/s12916-015-0469-2.

Singh P (2018) Scholarly Publishing in India: The Mapping of Open Access Journals Indexed in DOAJ. Chinese Librarianship 45: 29-42.

Small H (2013) The value of the humanities. Oxford, UK: Oxford University Press.

Smith ML and Reilly KMA (eds) (2014) Open development: Networked innovations in international development. Cambridge, MA:The MIT Press.

Smith ML and Seward RK (eds) (2020) Making open development inclusive: Lessons from IDRC research. Cambridge, MA: The MIT Press.

Solomon DJ and Björk B-C (2012) A study of open access journals using article processing charges. Journal of the American Society for Information Science and Technology 63(8): 1485-1495. DOI: 10.1002/asi.22673. 
Suber P (2003) The taxpayer argument for open access. SPARC Open Access Newsletter. Available at: https:// dash.harvard.edu/bitstream/handle/1/4725013/suber_taxpayer.htm?sequence=1 (accessed 15 January 2019).

Suber P (2007) Progress toward an OA mandate at the NIH, one more time. Available at: http://legacy. earlham.edu/ peters/fos/newsletter/08-02-07.htm\#nih (accessed 20 March 2020).

Suber P (2009) Knowledge as a public good. SPARC Open Access Newsletter. Available at: http://legacy. earlham.edu/ peters/fos/newsletter/11-02-09.htm (accessed 15 January 2019).

Suber P (2016) Knowledge unbound: Selected writings on open access, 2002-2011. Cambridge, MA: MIT Press.

Swartz A (2008) Full text of "Guerilla Open Access Manifesto". Available at: https://archive.org/stream/GuerillaOpenAccessManifesto/Goamjuly2008_djvu.txt (accessed 25 January 2020).

Swartz A and Lessig L (2016) The Boy Who Could Change the World: The Writings of Aaron Swartz. New York, NY: New Press.

Tanner S (2017) Gold is a dead model for Open Access Books. When the data hit the fan. Available at: http:// simon-tanner.blogspot.co.uk/2017/06/gold-is-dead-model-for-open-access-books.html (accessed 19 May 2018).

Tennant J, Agarwal R, Baždarić K, et al. (2020) A tale of two 'opens': intersections between Free and Open Source Software and Open Scholarship. SocArXiv. Available at: 10.31235/osf.io/2kxq8 (accessed 13 July 2020).

Tennant JP, Waldner F, Jacques DC, Masuzzo P, Collister LB and Hartgerink CHJ (2016) The academic, economic and societal impacts of Open Access: an evidence-based review. F1000Research. DOI: 10.12688/ f1000research.8460.3.

Trotter $\mathrm{H}$ and Hodgkinson-Williams C (2020) Open Educational Resources and Practices in the Global South: Degrees of Social Inclusion. In: Smith ML and Seward RK (eds) Making open development inclusive: Lessons from IDRC research. Cambridge, MA: The MIT Press, pp. 317-356.

Vanclay JK (2012) Impact factor: outdated artefact or stepping-stone to journal certification? Scientometrics 92(2): 211-238. DOI: 10.1007/s11192-011-0561-0.

Willinsky J (2006) The access principle: The case for open access to research and scholarship. Cambridge, MA: MIT Press.

Wright EO (2019) How to be an anticapitalist in the twenty-first century. London, UK: Verso.

\section{Notes}

1 According to early estimates of about 10,000 articles annually published with Wiley, the annual costs for the deal with this one publisher alone will amount to $€ 27,500,000$ plus additional publishing fees; see: Knöchelmann (2019b). 